\begin{tabular}{l|l|l|l|l}
\hline Volume 1 & Issue 1 & April (2020) & DOI: 10.47540/ijsei.v1i1.7 & Page: $11-15$ \\
\hline
\end{tabular}

\title{
The Role of Clove Farmer's Wife in Meeting Household Needs
}

\author{
Rika Malia Putri ${ }^{1}$, Bahtiar ${ }^{2}$, Dewi Anggraini ${ }^{3}$ \\ ${ }^{1,2,3}$ Department of Sociology Halu Oleo University, Indonesia \\ Corresponding Author: Rika Malia Putri; Email: rikamaliaputri98@gmail.com
}

\begin{tabular}{|c|c|}
\hline A R T I & E I N F O \\
\hline $\begin{array}{l}\text { Keywords } \\
\text { Wives; Cl }\end{array}$ & $\begin{array}{l}\text { Meeting Needs; T } \\
\text { ve Farmers. }\end{array}$ \\
\hline Received & $: 11 \mathrm{Jar}$ \\
\hline Revised & : 07 February 2020 \\
\hline Accepted & : 20 March, 2020 \\
\hline
\end{tabular}
A B S T R A C T

This study aims to discover the role and driving factors of the clove farmer's wife in meeting household needs in Patowonua Village, Lasusua District, North Kolaka Regency. The research approach used is descriptive qualitative, which is intended to describe reality in explanations and descriptive narratives. Data obtained through interview and observation techniques in the Patowonua Village community. The results of this study indicate that the role of the wife of a clove farmer in meeting household needs is helping the husband grow crops; managing household finances; sell the results of farming; borrow money from family; participate in producing agricultural commodities. The participation of clove farmer's wives in meeting household needs is driven by several factors, namely the desire to increase family income; to fill in spare time; and there is an encouragement of interest to help her husband.

\section{INTRODUCTION}

Indonesia is known as an agrarian country because most of its residents make a living in agriculture. The country of Indonesia benefits from being blessed with favorable natural conditions such as vast expanses of land, abundant biodiversity, and tropical climates where sunlight occurs throughout the year so that it can plant throughout the year. The reality of natural resources like this is naturally able to turn Indonesia into a prosperous country and fulfilling the food needs of all its citizens. Although not yet optimal, agriculture has become a real sector that has a very significant role in helping the country's foreign exchange earnings (Warsani, 2013).

Work as a farmer is one alternative to be able to maintain life in the village, where this work is done by not requiring high knowledge but can use physical energy. For some peasant communities who are poor even though they feel a heavy burden to meet various needs of life, this simple job can send children to a wage that is not set so that it can meet the needs of food, drink, and clothing (Khairani, 2010).

The agricultural sector in Indonesia is a sector that is quite resilient compared to other sectors. Products from the agricultural sector become one of the sources of foreign exchange income for the country. These commodities come from plantations, one of which is clove plantation products (Hendra, 2013).

Clove in Indonesia was once an export commodity by the government and has a very high economic value. The current conditions are inversely proportional to what happened in the past. Cloves are now imported. The beginning of the glory of clove farmers occurred in the $1950 \mathrm{~s}$ to $1970 \mathrm{~s}$, the price of $1 \mathrm{~kg}$ of cloves was equal to $1 \mathrm{~g}$ of gold at that time. To harmonize the return of prices, the government conducted a clove self-sufficiency program. This program succeeded in reaching the target, even the production of cloves exceeded the needs of the national clove. Excessive production reverses the situation, and this has a major impact on small farmers in rural areas. In 1990-1998, the price of clove which was originally very high dropped to a very low level (Prostowo et al, 2007).

Clove farmers also have families that they must care for and live like other families in general. The success factor in a household is the fulfillment of all the needs of family members such as clothing, shelter, food, and education, but currently experienced by clove farmers where the results of clove farming can only be picked once a year if the 
weather supports even once every 2 years and prices unstable impact on the difficulty of clove farmers in fulfilling their living needs so that they motivate to do various ways to meet the needs of their family's life, to get around this the farmers often do side jobs besides farming cloves, whether it be raising livestock, trading, etc., This is done to meet the needs of individuals and their families.

Patowonua village is one of the areas that earn a living as a clove farmer where most of the villagers depend on clove farming for their livelihoods, the participation of the wives of clove farmers is enthusiastic in meeting the needs of their families. We can see that women in the context of the nation and state are not only seen in urban communities, but also rural communities, and even rural populations with low educational backgrounds. However, insufficient or insufficient economic needs greatly induce every woman to be responsive, ie participate in meeting the basic needs of the household.

In relation with this, the role of farmer's wives in meeting household needs, especially clove farmers in Patowonua village, is important, whether their needs are fulfilled or not is affected by yields where clove yields are greatly influenced by what weather conditions if the weather is not favorable such as the occurrence of the rainy season and prolonged drought can result in clove farmers failing to harvest coupled with unstable clove prices where when abundant yields prices go down and when yields are few or even crop failures clove prices rise, conditions like these make it difficult for clove farmers in meeting the needs of his family's life if he only hopes of the uncertain outcome of the clove harvest, the wives of the clove farmers in Patowonuwa Village play a role in helping to fulfill their household needs such as working in services, trading, entrepreneurship, agricultural laborers, etc. All that was done by the wife of a clove farmer in Patowonua Village to be able to meet the needs of her family's life.

Based on the above background, this study aims to determine the role and driving factors of the clove farmer's wife in meeting household needs in Patowonua Village, Lasusua District, North Kolaka Regency.

\section{MATERIALS AND METHODS}

This research has been carried out in Patowonua Village, Lasusua District, North Kolaka Regency. The choice of location is based on the consideration that at that location there are many clove farmers in meeting their daily needs and various ways of dealing with the economy. Based on the title of the research developed, this type of research is to use qualitative and quantitative descriptive where the research seeks to study and describe the data obtained in the field about the Role of Clove Farmer's Wives in Meeting Household Needs in Patowonua Village, Lasusua District.

The selection of informants in this study using purposive sampling, the informants consisted of 15 clove farmers by trying to give a descriptive description or description of objectivity that was examined systematically and actually about the existing factors with the relevant consideration being able to answer and provide information regarding the role of the clove farmer's wife in meeting household needs in Patowonua Village, Lasusua District.

The type of data used is quantitative data and qualitative data. Quantitative data is data information in the form of symbols of numbers or numbers. This data is needed to show the population, percentage of education level, and employment of the Patowonua Village Community. Qualitative data is data information in the form of explanations and descriptions described. Data will be obtained through a process using direct analysis techniques. Namely by conducting interviews, observations, or observations on the Patowonua Village community.

According to Lofland (Moleong, 2002), the main data sources in qualitative research are words and actions, the rest is additional data such as documents and others. The data sources that will be obtained are:

1. Primary Data is data sourced from the results of interviews (interviews) directly from informants and observations (observations) researchers in the field of informants.

2. Secondary data is data sourced from the library, previous research reports (scientific research reports/journals), books, and documentation in the form of photos that are relevant to the research topic. 
The data collection techniques in this study using the method:

1. Observation (observation), namely by observing directly to get a picture of the role of the wife of clove farmers in meeting household needs in Patowonua Village, Lasusua District, North Kolaka Regency.

2. Interview, this data collection technique is done by asking questions verbally and directly (face to face) with informants who are supported by interview guidelines. To obtain information about the role of the clove farmer's wife in meeting household needs in Patowonua Village, Lasusua District, North Kolaka Regency.

3. Documentation, namely in the collection of data through written relics (documents) such as population data, livelihood data, and location descriptions as well as photographic evidence when conducting interviews with research subjects and informants. In this research, documentation is used to obtain data related to the research objectives.

This research uses descriptive qualitative analysis techniques by collecting data through observation, interviews, and documentation. The data obtained will be presented in the form of explanations, descriptions and illustrate the real reality so that it becomes clear about the role of the clove farmer's wife in meeting household needs in Patowonua Village, Lasusua District, North Kolaka Regency.

\section{RESULTS AND DISCUSSION}

\section{The Role of Clove Farmer's Wife in Meeting Household Needs}

a. Helping Husband in Farming Business

Planting is one of the activities carried out by most farmers, especially clove farmers in Patowonua Village, Lasusua Subdistrict, North Kolaka Regency., because clove farmland is difficult to work with if it only relies on 1 laborer, in this case, the husband by curiosity sometimes clove farmers ask for help from family members or pay others to work in their gardens but to save costs in starting a clove farming business namely farming The Patowonua village prefers to use their family members in the farming business, in this case, the wife who helps her husband work in the garden.

\section{b. Manage Farmer Household Finances}

Income from farm households is often seen as insufficient to finance the increase in a farming business, because in general farm households in Indonesia are small farmers and have low capital. Of course, with insufficient or erratic income obtained so that the wife of a farmer plays an important role in managing the financial business of farming. In fulfilling the basic needs of the farmer's wife the household has a very important role in managing the finances of the farming business, where the difficulties experienced by the income earned are uncertain to make the farmer's wife arrange financial for the farming business to meet the basic needs of the household.

c. Selling Farming Products

Selling the results of farming is one of how the wife of a clove farmer meets her family's needs. The wife of the clove farmer plays an important role in the clove farming business, in this case, it is carried out for the needs of the family, both for food, education and other needs, in fulfilling the needs of the family of the clove farmer's wife in Patowonua Village by selling farm produce to collectors or traders.

\section{d. Borrowing Money}

Loans are providers of money or bills based on loan agreements or agreements between the financing party and other parties, for example borrowing money from neighbors, friends, and family. The results of this study indicate that borrowing money for business capital or daily needs is an option that must be undertaken by some clove farmers in Patowonua Village, Lasusua District, North Kolaka Regency. The role of the farmer's wife in meeting household needs by borrowing money from her family to meet the basic needs of her household.

\section{e. Join Farm Business Activities}

Farming is a process of agricultural business in the strict sense that aims to produce an agricultural commodity. Farming is the management of natural resources, labor, capital and other skills to produce an agricultural product effectively and efficiently. In connection with this, the wife of a clove farmer in Patowonua Village plays an active role in farming activities carried out by her husband to help meet the needs of family life. 


\section{Encouraging Factors of Clove Farmer's Wives in Meeting Household Needs}

\section{a. Increase Family Income}

To increase the family income of the farmer's wife, they play a role in meeting the basic needs of the household. Based on the research results, it can be seen that most of these housewives work outside the home to supplement the family income. This is done where the economic challenges of the family are increasingly felt by housewives. This is caused because their lives are directly confronted by the consumption manager of the family, wife or housewife every day as an economic manager for the household must wrestle with the income and household expenditure budget where they are required to manage the income received from husband, determine which expenditure should be prioritized first and which do not and regulate the income it receives so that it can meet the needs in the family, conditions of inadequacy is what causes housewives or wives to participate in earning a living to increase family income.

\section{b. Want to be Independent}

Based on the results of the study, one of the factors that drive housewives to make a living so that the economy does not depend on the husband where what is meant here is if the wife or housewife wants to buy something or need something for her household needs she can buy it without asking her husband.

\section{c. Fill in Leisure Time}

Based on the research, it can be seen that one of the factors that drive housewives to help their husbands earn extra income is to fill the free time where most housewives only spend their time at home.

\section{d. Have an Interest}

Interest is one's awareness of an object, a problem or situation that contains a relationship with him, three factors cause interest, namely the encouragement of the individual, social impulse and motives and emotional impulse. The emergence of interest in the individual comes from the individual himself, and then the individual conducts interactions with his environment that cause social encouragement and emotional drive.
The interest of a wife to help her husband especially the wife of a clove farmer in Patowonua Village in terms of increasing family income arises because of a gap between expectations and the fact that the results of their clove farming have not been able to meet their household needs. to the condition where the clove farmer's family has difficulties in terms of the economy and the fulfillment of the necessities of life, such conditions are a factor in the emergence of the interest of the clove farmer's wife to play a role in meeting the needs of their household life.

\section{CONCLUSION}

The role of the clove farmer's wife in meeting household needs is a). Helping husband in a farming business, helping husband in farming is one of the activities carried out by most farmer's wives in meeting household needs and this is also done to save money. b). Regulate the farmer's household finances, income derived from farmer households is often seen as insufficient to finance the improvement of his farming business, because in general farmer households in Indonesia are small farmers and have low capital in meeting household needs. c). Selling the results of farming, clove farmer's wife plays an important role in clove farming, in this case, is done for the needs of families both food, education, and others. d). Borrowing money, borrowing money from family or relatives is one that is done by the farmer's wife in terms of meeting her household needs and also for capital and business. e). Join farming activities, which aim to produce an agricultural commodity. Farming is the management of natural resources, labor, capital and other skills to produce an agricultural product effectively and efficiently.

Factors that encourage the wife of a clove farmer in meeting household needs are a). To increase family income, it is known that most of these housewives work outside the home to supplement the family income. b). So that the economy does not depend on the husband, this is done so that housewives do not depend entirely on the husband in terms of meeting the needs of the household. c). To fill free time, the wives help their husbands to find extra income which is due to fill the free time where most of the wives only spend their time only at home. d) Having an interest, the 
interest of a wife to help her husband in increasing family income arises because of the great willingness to supplement income and meet the needs of his household.

\section{REFERENCES}

Hendra, J. H. (2013). Strategi Pengembangan Agribisnis Komoditas Cengkeh Dalam Meningkatkan Pendapatan Petani di Kabupaten Trenggalek. Jurnal Manajemen Agribisnis, 13(2) : 45-46.

Khairani, A. (2010). Pertumbuhan dan Produksi Kailan (Brassica Oleraceae var. Acephala) pada Berbagai Media Tanaman dan Pupuk Organic Cair. Skripsi. Fakultas Pertanian. Universitas Sumatera Utara

Warsani, H. (2013). Kajian Pemanfaatan Lahan Sawah di keacamatan Kuantan tengah Kabupaten Kuantan Singingi. Universitas Pendidikan Indonesia

Prastowo dkk. (2007). Prospek dan Arah Pengembangan Agribisnis Cengkeh. Badan Penelitian dan Pengembangan Pertanian. Deptan. 